\title{
Possibilities of verification of a short-term functional outcome prognosis in the acute period of spontaneous supratentorial intracerebral hemorrhage using modified variants of the Intracerebral Hemorrhage Scale
}

\author{
A. A. Kuznietsov \\ Zaporizhzhia State Medical University, Ukraine
}

The main purpose of the study was to analyze a diagnostic informative value of modified variants of the Intracerebral Hemorrhage Scale as techniques for detecting adverse functional outcome risk in the acute period of spontaneous supratentorial intracerebral hemorrhage (SSICH).

Materials and methods. A total of 122 conservatively treated patients (mean age was $64.7 \pm 1.1$ years old) in the acute period of SSICH were enrolled in a prospective study. Clinical and neuroimaging assessment of the patients' condition severity was conducted on admission to hospital using the ICH Scale and its modified versions (mICH-A, mICH-B). The value $>3$ in accordance with the modified Rankin Scale on the $21^{\text {st }}$ day of disease was considered as unfavourable functional outcome in SSICH. The ROC analysis was used for the comparative analysis of the scales' informative value and for the criteria development.

Results. The unfavourable functional outcome in the acute period of SSICH was registered in $50(41.0 \%)$ patients. These patients at the disease onset had significantly higher values in accordance with the mICH-A Scale $(4(3 ; 5)$ versus $2(1 ; 3), P<0.0001)$ and the $\mathrm{mICH}-\mathrm{B}$ Scale $(3(2 ; 4)$ versus $1(0 ; 2), \mathrm{P}<0.0001)$. It was determined that modified versions of the ICH Scale was more accurate than the original ICH Scale as for a short-term functional prognosis verification ( $A U C_{\text {mICH-A }} 0.81 \pm 0.04(0.73-0.88)$ versus $\mathrm{AUC}_{I C H} 0.74 \pm 0.04, \mathrm{P}=0.0062 ; \mathrm{AUC}_{\text {mICH-B }} 0.80 \pm 0.04(0.72-0.87)$ versus $\left.\mathrm{AUC}_{I \mathrm{CH}} 0.74 \pm 0.04, \mathrm{P}=0.0104\right)$, whereas the $\mathrm{mICH}-\mathrm{A}$ Scale scores $>2$ became the predictors of an unfavourable functional outcome in the acute period of disease (sensitivity $=76.0 \%$; specificity $=69.4 \% ; R R=3.6(3.1-4.1), P<0.0001)$ as well as the $\mathrm{mlCH}-\mathrm{B}$ Scale scores $>1$ (sensitivity $=76.0 \%$; specificity $=68.1 \%$; $\mathrm{RR}=3.2(2.8-3.6), \mathrm{P}<0.0001)$.

Conclusions. Modified versions of the ICH Scale are informative tools for the verification of a short-term functional prognosis in patients with $\mathrm{SSICH}$.

Можливості верифікації короткострокового функціонального прогнозу наслідків гострого періоду спонтанного супратенторіального внутрішньомозкового крововияиву з використанням модифікованих варіантів Intracerebral Hemorrhage Scale

\section{А. А. Кузнєцов}

Мета роботи - здійснити аналіз діагностичної інформативності модифікованих варіантів Intracerebral Hemorrhage (ICH) Scale в детекції ризику несприятливого функціонального виходу гострого періоду спонтанного супратенторіального внутрішньомозкового крововиливу (ССВМК).

Матеріали та методи. Провели проспективне дослідження 122 пацієнтів (середній вік $64,7 \pm 1,1$ року) в гострому періоді ССВМК на тлі консервативної терапії. Клініко-нейровізуалізаційне оцінювання тяжкості стану пацієнтів здійснювали під час надходження в стаціонар з використанням ICH Scale та її модифікованих варіантів (mICH-A, mlCH-B). Як несприятливий фуннціональний результат гострого періоду ССВМК розглядали значення > 3 балів за модифікованою шкалою Ренкіна на 21 добу захворювання. Для порівняльного аналізу інфоормативності використаних шкал і розроблення критеріїв прогнозування, використовували ROC-аналіз.

Результати. Несприятливий функціональний вихід гострого періоду ССВМК зареєстрований у 50 (41,0\%) пацієнтів. Пацієнти з несприятливим функціональним виходом гострого періоду ССВМК у дебюті захворювання статистично значущо відрізнялися вищими значеннями за шкалами mICH-A (4 (3; 5) проти $2(1 ; 3)$, p < 0,0001) та mICH-B $(3(2 ; 4)$ проти 1 (0; 2), p < 0,0001). Встановили, що модиффіковані варіанти ICH Scale перевищують оригінальну шкалу ICH за точністю верифікації короткострокового

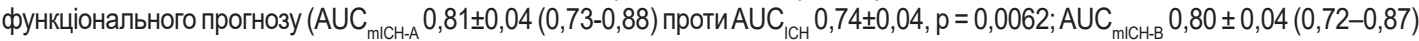
проти $\left.\mathrm{AUC}_{\mathrm{CH}} 0,74 \pm 0,04, \mathrm{p}=0,0104\right)$, при цьому предикторами несприятливого функціонального виходу гострого періоду захворювання є значення >2 балів за шкалою $\mathrm{mICH}-\mathrm{A}$ (чутливість $=76,0 \%$; специфічність $=69,4 \%$; RR = 3,6 $(3,1-4,1), p<$ 0,0001) та >1 бала за шкалою mICH-B (чутливість = 76,0\%; специфічність $=68,1 \%$; RR = 3,2 $(2,8-3,6), p<0,0001$ ).

Висновки. Модифіковані варіанти ICH Scale є інформативними інструментами верифікації короткострокового функціонального прогнозу в пацієнтів із ССВМК.

Возможности верификации краткосрочного функционального прогноза исхода острого периода спонтанного супратенториального внутримозгового кровоизлияния с использованием модифицированных вариантов Intracerebral Hemorrhage Scale

\section{А. А. Кузнецов}

Цель работы - провести анализ диагностической информативности модифицированных вариантов Intracerebral Hemorrhage (ICH) Scale в детекции риска неблагоприятного функционального исхода острого периода спонтанного супратенториального внутримозгового кровоизлияния (ССВМК).

Киючевые слова: внутримозговое кровоизлияние, прогноз. 
Материалы и методы. Проведено проспективное исследование 122 пациентов (средний возраст 64,7 $\pm 1,1$ года) в остром периоде ССВМК на фоне консервативной терапии. Клинико-нейровизуализационная оценка тяжести состояния пациентов проведена при поступлении с использованием ICH Scale и ее модифицированных вариантов (mICH-A, mICH-B). В качестве неблагоприятного функционального исхода острого периода ССВМК рассматривали значение >3 балла по модифицированной шкале Рэнкина на 21 сутки заболевания. Для сравнительного анализа информативности использованных шкал и разработки критериев прогнозирования, использовали ROC-анализ.

Результаты. Неблагоприятный функциональный исход острого периода ССВМК зарегистрирован у $50(41,0 \%)$ пациентов. Пациенты с неблагоприятным функциональным исходом острого периода ССВМК в дебюте заболевания статистически значимо отличались более высокими значениями по шкалам $\mathrm{mICH}-\mathrm{A}(4(3 ; 5)$ против $2(1 ; 3), \mathrm{p}<0,0001)$ и mICH-B $(3(2 ; 4)$ против 1 (0; 2), p < 0,0001). Установлено, что модисициированные варианты ICH Scale превосходят оригинальную шкалу ICH по точности верификации краткосрочного функционального прогноза $\left(\mathrm{AUC}_{\text {mICH-A }} 0,81 \pm 0,04(0,7-0,88)\right.$ против $\mathrm{AUC} \mathrm{CHH}_{\text {ICH }}$ $0,74 \pm 0,04, p=0,0062 ; A^{\prime} C_{\text {mICH-в }} 0,80 \pm 0,04(0,72-0,87)$ против $\left.A U_{I C H} 0,74 \pm 0,04, p=0,0104\right)$, при этом предикторами неблагоприятного функционального исхода острого периода заболевания выступают значения >2 балла по шкале $\mathrm{mlCH}-\mathrm{A}$ (чувствительность = 76,0\%; специфичность = 69,4\%; RR = 3,6 $(3,1-4,1), p<0,0001)$ и >1 балла по шкале mICH-B (чувствительность $=76,0 \%$; специфиичность $=68,1 \%$; $R R=3,2(2,8-3,6), p<0,0001)$.

Выводы. Модифицированные варианты ICH Scale являются информативными инструментами верификации краткосрочного функционального прогноза у пациентов со ССВМК.

The choice of optimal tactics for patient management with spontaneous supratentorial intracerebral hemorrhage (SSICH) is one of the most difficult and, unfortunately, still unsolved problems in modern neurology [1]. It is highly important from the medical and social point of view due to leading positions of this pathology in the cause-of-death and disability structure among the adult population in most countries of the world $[2,3]$.

One of the most effective ways of solving the problem is to develop a differentiated approach to the optimal treatment strategy choice, taking into consideration an individual shortterm prognosis $[1,4]$. In this context, it is appropriate to use the tools of clinical neuroimaging assessment of the severity at the disease onset. The "gold standard" in this area is the original Intracerebral Hemorrhage $(\mathrm{olCH})$ Scale, which demonstrated a high informative value when used to detect the risk for a lethal outcome of acute hemorrhagic stroke $[5,6]$.

At the same time, the results of our previous study showed a significantly lower informative value of the olCH Scale when used to evaluate a short-term functional prognosis in this cohort of patients [7]. All of the above justifies the search for alternative tools for clinical neuroimaging scoring. In view of these facts, our attention was drawn to modified versions of the olCH Scale [8]. Available research literature did not reveal any information on the studies related to the development of criteria for the short-term functional outcome after SSICH in the acute period using modified olCH Scale variants.

\section{The aim}

The aim of the study was to analyze a diagnostic informative value of modified variants of the Intracerebral Hemorrhage Scale as techniques for detecting adverse functional outcome risk in the acute period of $\mathrm{SSICH}$.

\section{Materials and methods}

The study included 122 patients with SSICH ( 65 men and 57 women, the mean age was $64.7 \pm 1.1$ years old) who were admitted to the Brain Circulation Disorders Department of the Municipal Institution "Zaporizhzhia City Clinical Hospital No 6" within the first 24 hours from the disease onset and underwent conservative therapy.
The diagnosis was confirmed by the results of a neuroimaging study, which was performed on admission with the use of a computed tomography scanner "Simens Somatom Spirit". The site and size of lesion, midline shift and a secondary intraventricular hemorrhage (SIVH) presence were assessed. The lesion size ( $\mathrm{ICH}$ volume) was calculated based on ellipsoid formula: $\mathrm{ICH}$ volume $(\mathrm{mL})=a^{*} b^{*} \mathrm{c}$, where $a, b$ and $c$ are linear sizes of lesion $(\mathrm{mm})$. The severity of a SIVH was evaluated using the Graeb Scale.

Integral clinical and neuroimaging assessment of the patients' condition severity was conducted using the olCH score and its modified versions ( $\mathrm{mlCH}-\mathrm{A}, \mathrm{mlCH}-\mathrm{B}$ ). The functional outcome of SSICH in the acute period was assessed using the modified Rankin Scale (mRS), thus $m R S$ score $>3$ on the 21 st day after admission was considered as unfavourable functional outcome of the disease.

Statistical analysis of the obtained data was conducted using Statistica 13.0 software (StatSoft Inc., USA, series number JPZ804I382130ARCN10-J) and MedCalc (version 16.4). Shapiro-Wilk criterion was used in order to assess the distribution normality. As the distribution of the majority of indexes differed from a normal one, descriptive statistics were presented as a median and interquartile range. The intergroup differences were compared based on the MannWhitney criterion. AROC analysis was carried out to develop prognosis criteria and to evaluate their informative value. A $P$-value $<0.05$ was considered to be statistically significant.

\section{Results}

The unfavourable functional outcome in the acute period of $\mathrm{SSICH}$ was registered in $50(41 \%)$ patients. The frequency of the unfavourable outcome in the acute period of SSICH in patients with different values of the $\mathrm{mICH}-\mathrm{A}$ Scale score and $\mathrm{mICH}-\mathrm{B}$ Scale score is presented in Tables 1 and 2.

Based on comparison analysis, it was found that patients with unfavourable outcome in the acute period of $\mathrm{SSICH}$ had statistically higher values of the $\mathrm{mICH}$-A Scale score $(4(3 ; 5)$ versus $2(1 ; 3), \mathrm{P}<0.0001)$, the $\mathrm{mICH}-\mathrm{B}$ Scale score $(3(2 ; 4)$ versus $1(0 ; 2), \mathrm{P}<0.0001)$ and the olCH Scale score $(1(1 ; 2)$ versus $0(0 ; 1), P<0.0001)$ at the disease onset.

The gradations distribution of the $\mathrm{mICH}-\mathrm{A}$ Scale and $\mathrm{mICH}-\mathrm{B}$ Scale subtest values in comparison with the func- 
Table 1. The frequency of the unfavourable outcome in the acute period of SSICH in patients with different values of $\mathrm{mICH}-\mathrm{A}$ Scale score

\begin{tabular}{|l|l|l|}
$\begin{array}{l}\text { mICH-A } \\
\text { Scale score }\end{array}$ & $\begin{array}{l}\text { Total number } \\
\text { of patients }(\mathbf{n})\end{array}$ & $\begin{array}{l}\text { Unfavourable } \\
\text { functional outcome }(\%)\end{array}$ \\
\hline 0 & 4 & 25.0 \\
\hline 1 & 22 & 4.5 \\
\hline 2 & 36 & 27.8 \\
\hline 3 & 26 & 42.3 \\
\hline 4 & 18 & 61.1 \\
\hline 5 & 10 & 100.0 \\
\hline 6 & 3 & 100.0 \\
\hline 7 & 2 & 100.0 \\
\hline 8 & 1 & 100.0 \\
\hline
\end{tabular}

Table 2. The frequency of the unfavourable outcome in the acute period of SSICH in patients with different values of the $\mathrm{mICH}-\mathrm{B}$ Scale score

\begin{tabular}{l|l|l|}
$\begin{array}{l}\mathrm{m} \mathbf{m} \text { CH-B } \\
\text { Scale score }\end{array}$ & $\begin{array}{l}\text { Total number } \\
\text { of patients }(\mathrm{n})\end{array}$ & $\begin{array}{l}\text { Unfavourable } \\
\text { functional outcome (\%) }\end{array}$ \\
\hline 0 & 21 & 9.5 \\
\hline 1 & 40 & 25.0 \\
\hline 2 & 23 & 34.8 \\
\hline 3 & 21 & 71.4 \\
\hline 4 & 11 & 81.8 \\
\hline 5 & 2 & 100.0 \\
\hline 6 & 3 & 100.0 \\
\hline 7 & 1 & 100.0 \\
\hline
\end{tabular}

tional outcome in the acute period of $\mathrm{SSICH}$ is presented in Tables 3 and 4.

As the data shows, the presence and severity of SIVH (Pearson's chi-squared test statistic $=32.8$ for the $\mathrm{mICH}-\mathrm{A}$ Scale, $\mathrm{P}<0.0001$; Pearson's chi-squared test statistic $=32.6$ for the $\mathrm{mICH}-\mathrm{B}$ Scale, $\mathrm{P}<0.0001)$, as well as the patient's age (Pearson's chi-squared test statistic $=17.0$ for the $\mathrm{mICH}-\mathrm{A}$ Scale, $\mathrm{P}=0.0002$; Pearson's chi-squared test statistic $=15.0$ for the $\mathrm{mICH}-\mathrm{B}$ Scale, $\mathrm{P}<0.0001$ ) were associated with the functional outcome in the acute period of SSICH. At the same time, patients with different variants of the functional outcome of SSICH in the acute period were not only of different ages and the Graeb Scale score at the disease onset, but also they had different the Glasgow Coma Scale score and intracerebral hemorrhage volume (Table 5).

It was determined that the $\mathrm{ICH}$ Scale were less informative than the $\mathrm{mICH}-\mathrm{A}$ Scale (AUC $\pm \mathrm{SE}(95 \% \mathrm{Cl}$ ) $0.74 \pm 0.04(0.65-0.81)$ versus $0.81 \pm 0.04(0.73-0.88)$, $\mathrm{P}=0.0062)$ and the $\mathrm{mICH}-\mathrm{B}$ Scale $(\mathrm{AUC} \pm \mathrm{SE}(95 \% \mathrm{Cl})$ $0.74 \pm 0.04(0.65-0.81)$ versus $0.80 \pm 0.04(0.72-0.87)$, $P=0.0104)$ as a technique for detecting adverse functional outcome risk in the acute period of $\mathrm{SSICH}$, whereas the $\mathrm{mICH}-\mathrm{A}$ and $\mathrm{mICH}-\mathrm{B}$ Scales did not differ (the values $\mathrm{AUC} \pm \mathrm{SE}(95 \% \mathrm{Cl})$ accounting for $0.81 \pm 0.04(0.73-0.88)$ and $0.80 \pm 0.04(0.72-0.87), P=0.2771$, respectively) (Fig. 1).

The ROC-analysis showed, that $\mathrm{mICH}-\mathrm{A}$ Scale score $>2(\mathrm{Se}=76.0 \%$; Sp $=69.4 \%)$ and $\mathrm{mICH}-\mathrm{B}$ Scale score $>1$ ( $\mathrm{Se}=76.0 \%$; Sp $=68.1 \%$ ) were the predictors of unfavourable functional outcome in the acute period of
Table 3. The gradations distribution of the $\mathrm{mICH}-\mathrm{A}$ Scale subtest values in comparison with the functional outcome in the acute period of $\mathrm{SSICH}$

\begin{tabular}{|c|c|c|c|c|}
\hline Subtest & $\begin{array}{l}\text { Favourable functional } \\
\text { outcome }(n=72)\end{array}$ & $\begin{array}{l}\text { Unfavourable } \\
\text { functional outcome } \\
(n=50)\end{array}$ & $\begin{array}{l}\text { Pearson's } \\
\text { chi-squared } \\
\text { test statistic }\end{array}$ & $\mathbf{P}$ \\
\hline \multicolumn{5}{|l|}{ Age, years } \\
\hline$<50$ & $9(12.5 \%)$ & $1(2.0 \%)$ & \multirow{3}{*}{17.0} & \multirow{3}{*}{0.0002} \\
\hline $50-65$ & $35(48.6 \%)$ & $11(22.0 \%)$ & & \\
\hline$>65$ & $28(38.9 \%)$ & $38(76.0 \%)$ & & \\
\hline \multicolumn{5}{|c|}{ Glasgow Coma Scale score } \\
\hline $14-15$ & $55(76.4 \%)$ & $32(64.0 \%)$ & \multirow{4}{*}{6.6} & \multirow{4}{*}{0.0851} \\
\hline $9-13$ & $17(23.6 \%)$ & $14(28.0 \%)$ & & \\
\hline $6-8$ & $0(0.0 \%)$ & $2(4.0 \%)$ & & \\
\hline $3-5$ & $0(0.0 \%)$ & $2(4.0 \%)$ & & \\
\hline \multicolumn{5}{|c|}{ Intracerebral hemorrhage volume, $\mathrm{mL}$} \\
\hline$<30$ & $64(88.9 \%)$ & $37(74.0 \%)$ & \multirow{3}{*}{4.7} & \multirow{3}{*}{0.0959} \\
\hline $30-50$ & $5(6.9 \%)$ & $9(18.0 \%)$ & & \\
\hline$>50$ & $3(4.2 \%)$ & $4(8.0 \%)$ & & \\
\hline \multicolumn{5}{|c|}{ Graeb Scale score } \\
\hline 0 & $49(68.1 \%)$ & $16(32.0 \%)$ & \multirow{4}{*}{32.8} & \multirow{4}{*}{$<0.0001$} \\
\hline $1-4$ & $22(30.6 \%)$ & $14(28.0 \%)$ & & \\
\hline $5-8$ & $1(1.3 \%)$ & $18(36.0 \%)$ & & \\
\hline$\geq 9$ & $0(0.0 \%)$ & $2(4.0 \%)$ & & \\
\hline
\end{tabular}

Table 4. The gradations distribution of the mICH-B Scale subtest values in comparison with the functional outcome of $\mathrm{SSICH}$ acute period

\begin{tabular}{|c|c|c|c|c|}
\hline Subtest & $\begin{array}{l}\text { Favourable } \\
\text { functional outcome } \\
(n=72)\end{array}$ & $\begin{array}{l}\text { Unfavourable } \\
\text { functional outcome } \\
(n=50)\end{array}$ & $\begin{array}{l}\text { Pearson's } \\
\text { chi-squared } \\
\text { test statistic }\end{array}$ & $\mathbf{P}$ \\
\hline \multicolumn{5}{|l|}{ Age, years } \\
\hline$<65$ & $44(61.1 \%)$ & $12(24.0 \%)$ & 15.0 & $<0.0001$ \\
\hline$\geq 65$ & $28(38.9 \%)$ & $38(76.0 \%)$ & & \\
\hline \multicolumn{5}{|c|}{ Glasgow Coma Scale score } \\
\hline $14-15$ & $55(76.4 \%)$ & $32(64.0 \%)$ & 6.6 & 0.0851 \\
\hline $9-13$ & $17(23.6 \%)$ & $14(28.0 \%)$ & & \\
\hline $5-8$ & $0(0.0 \%)$ & $4(8.0 \%)$ & & \\
\hline $3-4$ & $0(0.0 \%)$ & $0(0.0 \%)$ & & \\
\hline \multicolumn{5}{|c|}{ Intracerebral hemorrhage volume, $\mathrm{mL}$} \\
\hline$<30$ & $64(88.9 \%)$ & $37(74.0 \%)$ & 4.7 & 0.959 \\
\hline $30-50$ & $5(6.9 \%)$ & $9(18.0 \%)$ & & \\
\hline$>50$ & $3(4.2 \%)$ & $4(8.0 \%)$ & & \\
\hline \multicolumn{5}{|c|}{ Graeb Scale score } \\
\hline 0 & $49(68.1 \%)$ & $16(32.0 \%)$ & 32.6 & $<0.0001$ \\
\hline $1-3$ & $19(26.4 \%)$ & $9(18.0 \%)$ & & \\
\hline$>3$ & $4(5.5 \%)$ & $25(50.0 \%)$ & & \\
\hline
\end{tabular}

SSICH, whereas the accuracy of a short-term functional prognosis verification using the $\mathrm{mICH}-\mathrm{A}$ and $\mathrm{mICH}$-B Scales accounted for $75.1 \%$ and $77.1 \%$, respectively, (Pearson's chi-squared test statistic $=1.01, \mathrm{P}=0.2945$ ).

It was determined that the $\mathrm{mICH}-\mathrm{A}$ Scale score $>2$ and the $\mathrm{mICH}-\mathrm{B}$ Scale score $>1$ were associated with the risk of an unfavourable functional outcome of $\mathrm{SSICH}$ in the acute period, multiplied by $3.6(\mathrm{RR} 95 \% \mathrm{Cl} 3.1-4.1, \mathrm{P}<0.0001)$ and 3.2, respectively, (RR $95 \% \mathrm{Cl} 2.8-3.6, \mathrm{P}<0.0001)$ (Table 6).

\section{Discussion}

In the course of the study, it was determined that the modified versions of the olCH Scale were informative tools to detect an individual risk for an unfavourable functional 
Table 5. Comparative analysis of clinical and neuroimaging criteria in patients with SSICH in comparison with the functional outcome in the acute period of disease

\begin{tabular}{|l|l|l|l|}
\hline Subtest & $\begin{array}{l}\text { Favourable } \\
\text { functional outcome } \\
(\mathbf{n}=72)\end{array}$ & $\begin{array}{l}\text { Unfavourable } \\
\text { functional outcome } \\
(\mathbf{n}=50)\end{array}$ & $\mathbf{P}$ \\
\hline Age, years & $63.0(56.0 ; 72.0)$ & $72.0(65.0 ; 76.0)$ & $<0.0001$ \\
\hline Glasgow Coma Scale score & $15(14 ; 15)$ & $14(12 ; 15)$ & 0.0439 \\
\hline Intracerebral hemorrhage volume, $\mathrm{mL}$ & $6.0(3.0 ; 15.9)$ & $13.9(4.7 ; 30.1)$ & 0.0152 \\
\hline Graeb Scale score & $0(0 ; 1)$ & $3(0 ; 5)$ & $<0.0001$ \\
\hline
\end{tabular}

Table 6. The resulting comparison of the mICH-A Scale and the $\mathrm{mICH}-\mathrm{B}$ Scale scores with the functional outcome of SSICH in the acute period.

\begin{tabular}{ll|l|l|l} 
Scale, score & & $\begin{array}{l}\text { Frequency of unfavourable } \\
\text { functional outcome }\end{array}$ & RR $(95 \%$ Cl $)$ & P \\
\hline mICH-A & $\begin{array}{l}\leq 2 \\
(n=61)\end{array}$ & $18.0 \%$ & $3.6(3.1-4.1)$ & $<0.0001$ \\
& $\begin{array}{l}>2 \\
(n=61)\end{array}$ & $63.9 \%$ & & \\
mICH-B & $\begin{array}{l}\leq 1 \\
(n=61)\end{array}$ & $19.7 \%$ & $3.2(2.8-3.6)$ & $<0.0001$ \\
& $\begin{array}{l}>1 \\
(n=61)\end{array}$ & $62.3 \%$ & & \\
& & & & \\
\hline
\end{tabular}

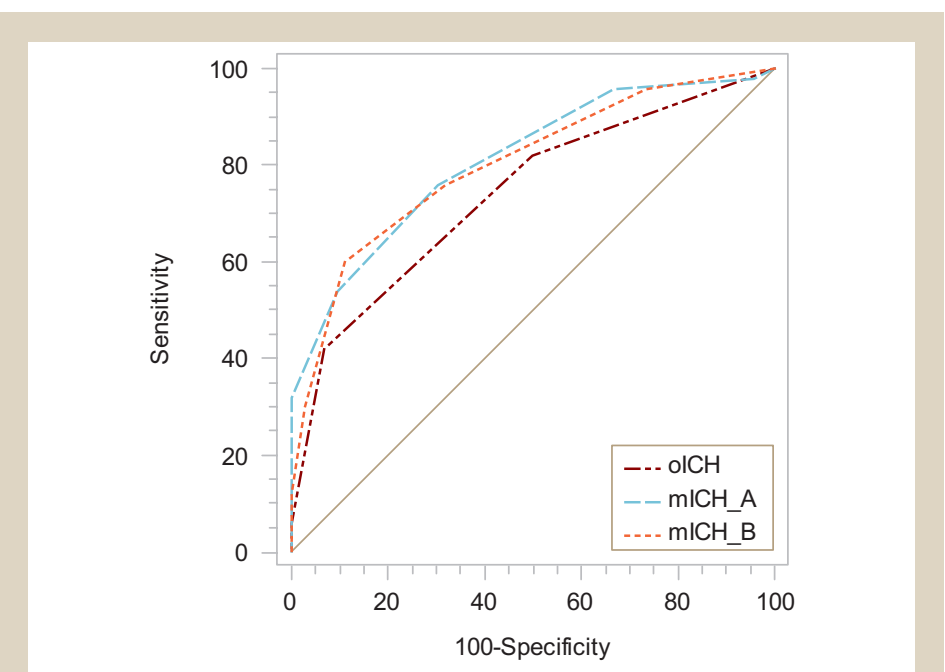

Fig. 1. Results of the ROC-analysis of the informative value of the olCH, mICH-A and $\mathrm{mICH}-\mathrm{B}$ Scales as techniques for detecting a short-term functional prognosis in the acute period of SSICH.

outcome of SSICH in the acute period. The AUC values of the specified scales $(\geq 0.80)$ corresponded to the gradation "very good" in accordance with the International Expert Scale for the quality of binary classifiers assessment (1993) [9]. In our opinion, a high informative value of these scales was supported by the integral assessment of clinical and neuroimaging data, which were associated with the outcome of disease in the acute period. The obtained data are consistent with the results of meta-analysis, which proved the prognostic value of the patient's age, initial level of consciousness and intracerebral hemorrhage volume in patients with cerebral hemorrhagic hemispheric stroke [10].

Based on the ROC analysis, the $\mathrm{mICH}-\mathrm{A}$ Scale score $(>2)$ and the $\mathrm{mICH}-\mathrm{B}$ Scale score $(>1)$ were determined along with an optimal sensitivity and specificity ratio, being associated with the risk of the $\mathrm{mRS}$ score $>3$ on the $21^{\text {st }}$ day of the disease, multiplied by $3.6(\mathrm{RR} 95 \% \mathrm{Cl}$ 3.1-4.1, $\mathrm{P}<0.0001$ ) and 3.2, respectively, (RR $95 \% \mathrm{Cl}$ 2.8-3.6, $P<0.0001)$. The accuracy of functional prognosis verification for $\mathrm{SSICH}$ outcome in the acute period using these criteria exceeded $75.0 \%$, while there were no statistically significant differences in the AUC values between the $\mathrm{mICH}-\mathrm{A}$ and $\mathrm{mICH}-\mathrm{B}$ Scales $(P=0.2771)$. At the same time, these scales had a higher informative value in comparison with the olCH Scale with regard to detection of an individual risk for an unfavourable functional outcome of $\mathrm{SSICH}$ in the acute period, which, in our opinion, was attributed to a quantitative assessment of SIVH severity, unlike the olCH Scale. The interrelation between the Graeb Scale score and the functional outcome of SSICH in the acute period was revealed (Pearson's chi-squared test $P<0.0001$ for both scales), which proves the above-mentioned hypothesis. The obtained data are consistent with the results of other studies, which demonstrated the negative effect of SIVH severity on the SSICH outcome $[11,12]$.

All of the above justifies the expediency of using the modified versions of the olCH Scale in order to make a short-term functional prognosis of $\mathrm{SSICH}$ outcome in the acute period.

\section{Conclusions}

1. Modified variants of the $\mathrm{ICH}$ Scale are informative tools for the verification of a short-term functional prognosis in patients with SSICH and are more accurate than the $\mathrm{ICH}$ Scale to detect an individual risk for an unfavourable functional outcome of disease in the acute period (AUC $_{\text {mICH-A }} 0.81 \pm 0.04(0.73-0.88)$ versus $\mathrm{AUC}_{\mathrm{olCH}} 0.74 \pm$ $0.04, P=0.0062 ; A_{\text {mICH-B }} 0.80 \pm 0.04(0.72-0.87)$ versus $\left.A C_{\text {OCH }} 0.74 \pm 0.04, P=0.0104\right)$.

2. Predictors of the mRS score $>3$ on the $21^{\text {st }}$ day of SSICH are the mICH-A Scale score $>2(\mathrm{Se}=76.0 \%$; $\mathrm{Sp}=69.4 \% ; \mathrm{RR} 95 \% \mathrm{Cl}=3.6(3.1-4.1), \mathrm{P}<0.0001)$ and the $\mathrm{mICH}-\mathrm{B}$ Scale score $>1(\mathrm{Se}=76.0 \%$; $\mathrm{Sp}=68.1 \%$; RR $95 \% \mathrm{Cl}=3.2(2.8-3.6), \mathrm{P}<0.0001)$.

The perspective for the further scientific research is to assess the informative value of modified versions of the ICH Scale for a short-term vital prognosis determination in patients with $\mathrm{SSICH}$.

Funding

The study is funded as a part of scientific research work at Zaporizhzhia State Medical University “Improving diagnosis and treatment of cerebral circulation disorders at different stages of the disease", number of state registration 0118 U007145 (2018-2023).

Conflicts of interest: author has no conflict of interest to declare. Конфлікт інтересів: віАсутній.

Надійшла Ао редакції / Received: 12.01.2019 Після Аоопрацювання / Revised: 24.01.2019 Прийнято Ао Аруку / Accepted: 01.02.2019

Information about author:

Kuznietsov A. A., MD, PhD, Associate Professor of the Department of Nervous Diseases, Zaporizhzhia State Medical University, Ukraine. 
Відомості про автора:

Кузнєцов А. А., канА. меА. наук, Аоцент каф. нервових хвороб,

Запорізький Аержавний медичний університет, Україна.

\section{Сведения об авторе:}

Кузнецов А. А., канА. меА. наук, Аоцент каф. нервных болезней, Запорожский государственный меАицинский университет, Украина.

\section{References}

[1] Kim, J. Y., \& Bae, H. J. (2017). Spontaneous Intracerebral Hemorrhage: Management. J Stroke, 19(1), 28-39. doi: 10.5853/jos.2016.01935

[2] An, S. J., Kim, T. J., \& Yoon, B. W. (2017). Epidemiology, Risk Factors, and Clinical Features of Intracerebral Hemorrhage: An Update. J Stroke, 19(1), 3-10. doi: 10.5853/jos.2016.00864

[3] Poon, M. T., Bell, S. M., \& Al-Shahi Salman, R. (2015). Epidemiology of Intracerebral Haemorrhage. Front Neurol Neurosci, 37, 1-12. doi: 10.1159/000437109

[4] Zahuranec, D. B., Fagerlin, A., Sánchez, B. N., Roney, M. E., Thompson, B. B., Fuhrel-Forbis, A., \& Morgenstern, L. B. (2016). Variability in physician prognosis and recommendations after intracerebral hemorrhage. Neurology, 86(20), 1864-1871. doi: 10.1212/ WNL.0000000000002676

[5] Nisar, T., Alchaki, A., \& Hillen, M. (2018). Validation of ICH score in a large urban population. Clin Neurol Neurosurg, 174, 36-39. doi: 10.1016/j.clineuro.2018.09.007

[6] Rahmani, F., Rikhtegar, R., Ala, A., Farkhad-Rasooli, A., \& Ebrahimi-Bakhtavar, H. (2018). Predicting 30-day mortality in patients with primary intracerebral hemorrhage: Evaluation of the value of intracerebral hemorrhage and modified new intracerebral hemorrhage scores. Iran J Neurol, 17(1), 47-52.

[7] Kuznietsov, A. (2018). Possibilities of clinical neuroimaging assessment scales using for patient severity in the onset of cerebral hemorrhagic supratentorial stroke to predict the outcome of the disease acute period. Zaporozhye medical journal, 20(1), 47-50. doi: 10.14739/23101210.2018.1.121990

[8] Hwang, B. Y., Appelboom, G., Kellner, C. P., Carpenter, A. M., Kellner, M. A., Gigante, P. R., \& Sander Connolly E. (2010). Clinical grading scales in intracerebral hemorrhage. Neurocrit Care, 13(1), 141-51. doi: 10.1007/s12028-010-9382-X

[9] Zweig, M. H., \& Campbell, G. (1993). Receiver-operating characteristic (ROC) plots: a fundamental evaluation tool in clinical medicine. Clin Chem, 39(4), 561-577.

[10] Gregório, T., Pipa, S., Cavaleiro, P., Atanásio, G., Albuquerque, I., Chaves, P. C., \&Azevedo, L. (2018). Prognostic models for intracerebral hemorrhage: systematic review and meta-analysis. BMC Med Res Methodol, 18(1), 145. doi: 10.1186/s12874-018-0613-8

[11] Specogna, A. V., Turin, T. C., Patten, S. B., \& Hill, M. D. (2014). Factors associated with early deterioration after spontaneous intracerebral hemorrhage: a systematic review and meta-analysis. PLoS One, 9(5), e96743. doi: 10.1371/journal.pone.0096743

[12] Ye, Z., Ai, X., Hu, X., Fang, F., \& You, C. (2017). Clinical features and prognostic factors in patients with intraventricular hemorrhage caused by ruptured arteriovenous malformations. Medicine (Baltimore), 96(45), e8544. doi: 10.1097/MD.0000000000008544 